DOI: http://dx.doi.org/10.17355/rkkpt.v23i4.87

\author{
BOGDÁN PÉTER*
}

\title{
Cigány gyerekek a Köznevelés címü folyóirat 1983 és 1987 között megjelent cikkeinek tükrében
}

\author{
Bevezetö
}

1 978 és 1998 között a pedagógiai szaksajtóban neveléstudósok, oktatáspolitikusok, oktatási szakértők és közírók tollából különböző oktatási stratégiák, oktatási modellek és módszerek, elképzelések láttak napvilágot arra vonatkozóan, hogy a roma gyermekeket miként lehetne vagy miként kellene nevelni. Mindezidáig azonban nem született olyan összefoglaló-elemző mü ezekröl a munkákról, amelynek segítségével ki lehetne mutatni, hogy az 1978 és 1998 között eltelt időben milyen nevelés-felfogásbeli tendenciák szerint, illetve nevelési elvek mentén rendeződtek el a különböző elképzelések a pedagógiai szaksajtóban. A romák oktatásával kapcsolatos kérdések a pedagógiai szaksajtó tükrében (1978-1998) címü készülő doktori disszertációm arra fog kísérletet tenni, hogy megállapítsa azt, milyen nagyobb merítésü, általános kategóriákba sorolhatók a tárgyalt húsz év javasolt oktatási stratégiái, modelljei és módszerei. Emellett az is vizsgálat tárgyát képezi, hogy a romákra vonatkozó történeti tudás megléte vagy éppen annak hiánya miképpen befolyásolta a roma gyermekek nevelhetöségére vonatkozó elképzeléseket, hogy a roma gyermekek problémáira vonatkozó válaszok mennyire illeszkedtek bele az adott korszak társadalom-felfogásába, iskolaelméletébe. Arra is kísérletet tesz a kutatás, hogy ezen folyamatokat és rendszerezést szociális és történeti-politikai keretekbe ágyazza.

* A szerző az MTA TK Kisebbségkutató Intézetének tudományos munkatársa. Email: bogdan.peter@tk.mta.hu

REGIO 23. évf. (2015) 4. szám 80-114. 
Köznevelés (1983-1987)

A jelen munkámban a kutatásom második merítése kerül az olvasók elé1, amelynek során a Köznevelés címü oktatási hetilap 1983 és 1987 között megjelent roma tematikájú írásait veszem górcső alá, s mivel a tárgyalt öt évben kevés, a roma gyermekekre vonatkozó, oktatási stratégia rajzolódott ki a vizsgálódásom során, a kutatást kiterjesztettem az összes olyan írásos anyagra is, amely valamilyen oknál fogva kapcsolódott a roma tematikához, vagy amelyben akár csak egyszer is előfordult - a kor szóhasználatának megfelelően - a cigány szó. Az elemzésben szereplő táblázatokból kiderül, hogy a kutatás alaphipotézisének megfelelő hét neveléspolitikai koncepció mellett ${ }^{2}-$ a közgondolkodásban bekövetkezett differenciálódás miatt - egyéb besorolásokra is sor került.

\section{3}

1983-ban a vizsgált szaklapban 22 olyan írás jelent meg, amely a cigány gyerekekkel foglalkozott, a következő kategóriákban:

\begin{tabular}{|c|c|}
\hline a roma tematika negligálása-modell & - \\
\hline $\begin{array}{c}\text { asszimiláció-modell } \\
\text { integráció-modell }\end{array}$ & 1 \\
\hline $\begin{array}{c}\text { szegregáció-modell } \\
\text { a cigánykérdés etnikus kérdésként való } \\
\text { felfogása-modell }\end{array}$ & 3 \\
\hline $\begin{array}{c}\text { a cigánykérdés szociális kérdésként való } \\
\text { felfogása-modell }\end{array}$ & 2 \\
\hline $\begin{array}{c}\text { asszimiláció-modell }- \text { a cigánykérdés } \\
\text { etnikus kérdésként való felfogása-modell }\end{array}$ & 1 \\
\hline $\begin{array}{c}\text { szegregáció-modell a cigánykérdés } \\
\text { etnikus kérdésként való felfogása-modell }\end{array}$ & 1 \\
\hline
\end{tabular}

\footnotetext{
${ }^{1}$ Az első merítés a következő volt: Bogdán Péter: Cigánygyerekek a Köznevelés című folyóirat tükrében (1978-1982). In: Iskolakultúra, 2011, 6-7. szám, 61-70. ${ }^{2}$ A pedagógiai szaksajtóban 1978 és 1998 között legalább hét neveléspolitikai koncepció jelenik meg: a roma tematika negligálása, az asszimiláció, az integráció, a szegregáció, a cigánykérdés etnikus kérdésként való felfogása, a cigánykérdés szociális kérdésként való felfogása, multikulturalizmus.
}

REGIO 23. évf. (2015) 4. szám 80-114. 


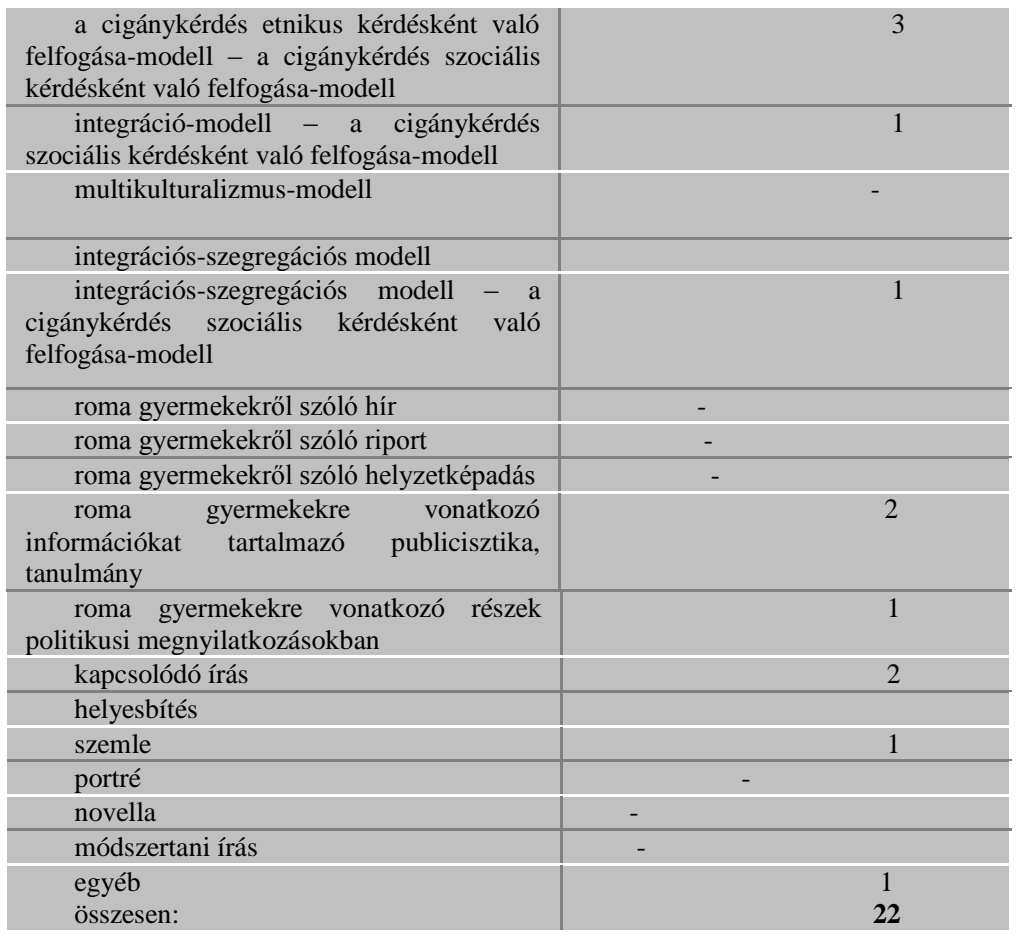

Az 1983-as évről az mondható el, hogy az 1978-1982-es időszakhoz képest a pedagógiai kutatók, oktatási és nevelési szakértök, valamint a különböző rovatokban megnyilvánuló tanárok és tanítók gondolkodása - a roma tematikát illetően - tovább variálódott.

Ebben az évben emiatt növekedett a szakcikkek tartalmát minősítő kategóriák száma is, amelynek során az figyelhető meg, hogy miközben a cigánykérdés etnikus kérdésként való felfogása rendkívüli módon felerősödött, aközben ez a fajta gondolkodás immáron összekeveredett azzal az asszimilációs, szegregációs, integrációs és szociális szemlélettel, amelyek a megelőző öt évben szinte kizárólagosan önálló minősítési kategóriákat képeztek.

Az 1983-ban keletkezett írásoknak fontos jellemzője az is, hogy döntö többségében a szerzők nem gondolkodtak abban, hogy az iskoláknak igazodnia kellene a szociális és etnikai hátterükben

REGIO 23. évf. (2015) 4. szám 80-114. 
jelentősen megváltozott gyermekösszetételhez. Szinte általánosan elmondható, hogy a szerzők azt fogalmazták meg: a tanulóknak kell hozzáidomulni a középosztályra szabott tanintézményi feltétekhez és nem csak szociálisan, de kulturálisan is, amelyböl fakadóan a cigány gyermekek és családjuk inkább bünbakokként voltak ábrázolva, semmint olyan közösségként, amelyen hatékonyan lehet segíteni a rendelkezésre álló pedagógiai eszköztár variálásával.

Csoma Gyula a Merre tart az iskolai felnöttoktatás? címü írásában - a fentebb leírtak szellemében - azt írta le, hogy a hagyományos felnőttképzésben egyre nagyobb teret nyernek a túlkoros roma tanulók, s ez az oktatási terep lehet az eszköze annak, hogy a cigány diákok minél hatékonyabban asszimilálódjanak.

Thuránszky Lehelné pályázati úton benyújtott. Kutya $a z$ üvegszekrényben címü novellájában egy olyan roma gyermeket mutatott be, akinek a családja előli egyetlen menekülési útvonal az volt, hogy iskolába jár, de mivel szükség volt az ő keresetére is, ezért az iskolához ellenségesen álló anya kiszakította őt a szakmunkásiskolából. A történet azt üzente 1983-ban, hogy a cigány gyerekek otthona mind infrastrukturálisan, mind egzisztenciálisan, mind szellemileg lerombolódott, s csak a jóindulatú iskola és a pedagógus lehet az ellenpont, amelynek következtében a föszereplő roma fiú tanult és sikeres munkássá vált.

A roma tematika etnikus alapon való megközelítését preferálta Novák Gábor Kutatómunka a Janus Pannonius Tudományegyetem Tanárképzö Karán címü írása is, amely Várnagy Elemér azon kutatásait ismertette, amelynek keretében hátrányos helyzetü roma gyermekek müvészeti és személyiségfejlesztésével foglalkozott, de ugyanez a témakör - B. Pongrácz Évával közösen jegyezve Várnagy Elemér tollából is terítékre került a Köznevelés hasábjain Hátrányos helyzetü gyermekek képzömüvészeti nevelése címmel. Ez utóbbi cikkből az derült ki, hogy a kutatást a hátrányos helyzetű gyermekekre szabták, mégis döntő többségében romákkal kapcsolatos elemzés született. Az írás megkérdőjelezte, hogy a cigány diákok képességbeli fejlettsége a környezeti adottságoktól függ. A szerzők csupán azt ismerték el, hogy ebben a tézisben van igazság, de sokkal inkább arra tették a voksot, hogy a roma tanulók nem roma társaikhoz képest - olyan pozitív adottságokkal rendelkeznek, amelyeket figyelembe kellene venni a fejlesztésük során. B.Pongrácz Éva és Várnagy Elemér ebben az írásban a 
negatív elöítéletek élét pozitívra változtatta, miközben nem számoltak azzal, hogy a pozitív elöítéletek is ugyanolyan alaptalan megközelítések, mint a negatívak, azaz - a jó szándék ellenére is olyan elméleti alapozással próbálkoztak, amely szintén magában hordozta a gyakorlati (etnikai alapon történö) elkülönítés veszélyét.

Balázs Mihály tollából Egy régen várt könyv olvasása közben címmel olyan írás jelent meg, amely elsősorban nem pedagógiai vonatkozású, sokkal inkább a romák és nem romák viszonyát taglalta. A szerző olvasmányai alapján visszautasította azt az állítást, hogy a romák iparosként az egész feudális Európát meghaladó tudással érkeztek meg mai lakhelyeikre, és elmélkedett azon is, hogy ha bár valóban igaz, hogy a II. Világháború után még a napszámos romákat is kiszorították a földosztásból, az akkor sem róható fel a többségi társadalomnak, mert a nem romák már sokkal régebben voltak földmüvelők, mint a cigányok.

Balázs Mihály írásában - általában - elutasította a cigánykérdés azon megközelítéseit, amelyek a többségi társadalmon kérik számon annak hibáit, mert szerinte ez történelmietlen, $\mathrm{s}$ olyan véleményalkotókkal szimpatizált (Várnagy Elemér, Báthory János, Vekerdi József), akikkel a roma értelmiségi réteg nem tudott vagy nem kívánt semmilyen formában azonosulni már a 80-as években sem.

Gyergyói Sándor A cigánytanulók oktatása Hajdú-Bihar megyében címü írása érdekes átmenetet képezett a szakcikkek között, amennyiben a cigánykérdést szociális kérdésként fogta fel, mégis megengedhetönek tartotta, hogy rövid időszakra, indokolt esetekben, csak a sikeres felzárkózás megtörténtéig, szegregálják a roma tanulókat, mielőtt integrált környezetbe helyeznék őket.

Czuczu Tibor (cigány származású szakfelügyelö) Cigánygyerekek az iskolában címü írása abból a szempontból volt figyelemre méltó, hogy tárgyalta a romák és nem romák, valamint az iskola és a cigány gyerekek, cigány szülők viszonyrendszerét. A szerző részletesen és hosszan elemezte azt, hogy milyen szociális háttere van a roma diákoknak és családoknak, konzekvenciát vont le arra vonatkozóan, hogy milyen reakciókat vált ki a hátrányos helyzet és a tanulatlanság, a nehéz szociális helyzet. Az írás tartalmazott kifejezetten negatív elöítéleteket, túlzásokat, rasszista megjegyzéseket és általánosításokat is a cigányokkal kapcsolatosan, ugyanakkor rendkívüli alapossággal adott konkrét tanácsokat arra

REGIO 23. évf. (2015) 4. szám 80-114. 
vonatkozóan, hogy egy pedagógusnak és egy iskolának miként és hogyan kell felkészülnie a számára idegen szociális és szocializációs környezetre, ha azt akarja, hogy a roma tanulók ugyanolyan sikeresek legyenek, mint nem roma társaik. Czuczu határozottan állást foglalt a cigány gyermekek beóvodáztatása mellett, mert szerinte az nemcsak a 8 . osztály sikeres elvégzését alapozza meg, de a továbbtanulást is.

Rácz Gyöngyi A cigánycsalád és az iskola címü írása sok tekintetben hasonlított Czuczu Tibor cikkéhez, amennyiben szintén részletekig menően tárgyalta a romák és nem romák kapcsolatrendszerét, valamint a roma diákok, szülök és az iskola viszonyát, az eredményesség, a hatékonyság mikéntjét. Ugyanakkor nagyon fontos eltérés volt az, hogy Rácz Gyöngyi a cigánykérdést kizárólagosan szociális kérdésként - és elöítéletmentesen - kezelte akkor, amikor a roma tanulók oktatási kérdéseiről volt szó. Czuczu Tiborhoz hasonlóan A cigánycsalád és az iskola címü cikk szerzője szintén nagy teret szentelt a pedagógiai instrukcióknak, de annak a széles tudásbázisnak is, amit a roma családok szociális adottságainak tárháza jelent. Rácz Gyöngyi tulajdonképpen azt a nézetét fejtette ki, hogy a romák és az iskola kapcsolatában a pedagógusnak van a legnagyobb felelössége, mert rajta múlik a harmonikus viszony kialakítása. Ebből a szempontból a tárgyalt írás mérföldkő, mert szakított azzal az alapállással, hogy minden iskolai kudarcért a cigányok a felelősek, s ezzel közvetve azt is sugallta: a pedagógusoknak és az iskolarendszernek kell alkalmazkodnia a megváltozott szociális és szocializációs hátterü gyermekösszetételhez.

Varjas Endre A pártfogolt címü filmkritikája szintén nem volt szorosan pedagógiai vonatkozású, de fontos megemlíteni, mert Rácz Gyöngyi írása mellett - kisebbségi véleményként - ez volt a másik olyan írás, amely amellett tette le a voksot, hogy a cigányság nem felelős a hátrányaiért, és a hátrányaiból következő szociális és szocializációs lemaradásáért.

Az 1983-as évben az integráció és a szegregáció kérdése nem jelent meg karakteresen. Csontos Magda Vanyarc új iskolája címü írása volt az egyetlen, amely a vanyarci cigányságot integrálódott közösségként ábrázolta, a szegregáció pedig csak felszínesen jelent meg, szinte közvetlenül nem is bizonyíthatóan, így Szabó László a

REGIO 23. évf. (2015) 4. szám 80-114. 
Kisdobosok a szakkörben és a Somogy megye müvelödésügyének helyzete címü írásokban.

Az év során az egyetlen politikai megnyilatkozást Aczél György a Minden változásban, minden korszerüsitésben érdekeltté kell tenni a nevelöket címü írásában tette. Ebben a politikus egyenrangú állampolgárokként ismerte el a romákat, úgy vélte, hogy 15-20 évvel korábban rosszabb volt a romák iskolázottsági mutatója, de elismerte azt is, hogy 1983-ban is van még mit tenni.

Összegezve az 1983-as évet az állapítható meg, hogy erősebbek voltak azok a hangok, amelyek a romákat hibáztatták az iskolai sikertelenségük miatt, mégpedig azért, mert a velük kapcsolatos oktatási problémákat nem pedagógiai eszközökkel, hanem etnikai alapállásból akarták megoldani. Integrációról szinte szó sem esett, de az viszont pozitívum, hogy a kizárólagos szegregáció is majdnem háttérbe szorult, miközben a szociális és tisztán pedagógiai megközelítések is teret kaptak.

1983-ban a két legjelentősebb írást Czuczu Tibor és Rácz Gyöngyi jegyezte, amelyek között, ha voltak is módszertani átfedések, mégsem lehet őket egy lapon említeni, mert az előbbi etnikus alapon - sokszor - elöítéletesen közelített a cigányokhoz, míg az utóbbi szociális alapon elutasította a prejudikálást. Ugyanakkor jelzi a két írás megjelentetése azt is, hogy maga a Köznevelés sem tudta eldönteni: hová tegye le a voksot?

\section{4}

1984-ben a Köznevelésben 22 írás jelent meg a következő kategóriákban:

\begin{tabular}{|c|c|}
\hline a roma tematika negligálása-modell & \\
\hline $\begin{array}{c}\text { asszimiláció-modell } \\
\text { integráció-modell }\end{array}$ & 3 \\
\hline $\begin{array}{c}\text { szegregáció-modell } \\
\text { a cigánykérdés etnikus kérdésként való } \\
\text { felfogása-modell }\end{array}$ & 2 \\
\hline $\begin{array}{c}\text { a cigánykérdés szociális kérdésként való } \\
\text { felfogása-modell }\end{array}$ & \\
\hline $\begin{array}{c}\text { asszimiláció-modell - a cigánykérdés } \\
\text { etnikus kérdésként való felfogása-modell }\end{array}$ & 2 \\
\hline $\begin{array}{c}\text { szegregáció-modell - a cigánykérdés } \\
\text { etnikus kérdésként való felfogása-modell }\end{array}$ & \\
\hline
\end{tabular}

REGIO 23. évf. (2015) 4. szám 80-114. 


\begin{tabular}{|c|c|}
\hline $\begin{array}{l}\text { a cigánykérdés etnikus kérdésként való } \\
\text { felfogása-modell - a cigánykérdés szociális } \\
\text { kérdésként való felfogása-modell }\end{array}$ & \\
\hline $\begin{array}{l}\text { integráció-modell }- \text { a cigánykérdés } \\
\text { szociális kérdésként való felfogása modell }\end{array}$ & \\
\hline multikulturalizmus-modell & \\
\hline integrációs-szegregációs modell & \\
\hline $\begin{array}{l}\text { integrációs-szegregációs modell }- \text { a } \\
\text { cigánykérdés szociális kérdésként való } \\
\text { felfogása-modell }\end{array}$ & \\
\hline $\begin{array}{l}\text { integrációs-szegregációs modell }- \text { a } \\
\text { cigánykérdés etnikus kérdésként való } \\
\text { felfogása-modell }\end{array}$ & 2 \\
\hline roma gyermekekről szóló hír & 2 \\
\hline roma gyermekekről szóló riport & \\
\hline roma gyermekekről szóló helyzetképadás & \\
\hline 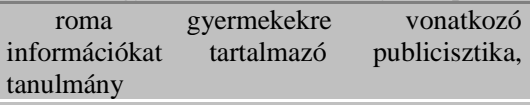 & 2 \\
\hline $\begin{array}{l}\text { roma gyermekekre vonatkozó részek } \\
\text { politikusi megnyilatkozásokban }\end{array}$ & 1 \\
\hline kapcsolódó írás & 6 \\
\hline helyesbítés & \\
\hline szemle & 2 \\
\hline portré & \\
\hline novella & \\
\hline módszertani írás & \\
\hline egyéb & \\
\hline összesen: & 22 \\
\hline
\end{tabular}

Ebben az évben egy kategóriával tovább bővült a minősítési címkék száma az integrációs-szegregációs modell - a cigánykérdés etnikus kérdésként való felfogása-modell bevezetésével. Azt is meg kell jegyezni, hogy felerősödött a halmozottan hátrányos helyzetü gyermekekről általánosságban fogalmazó beszéd, amelynek köszönhetően a 22 írásból 6 cikk csak a kapcsolódó írás minősítést kapta meg, annak okán, hogy a szerzők - döntő többségében egyszer sem írták le a cigány/roma szavakat, csupán csak sejteni lehet azt, hogy a statisztikai és egyéb mérési adatok mögött a cigány tanulókra (is) gondoltak.

Az első ilyen írás Martin László tollából született Szelekció az általános iskolában címmel, amelyben Ladányi János és Csanádi Gábor azonos címet viselö könyvét mutatta be a következő

REGIO 23. évf. (2015) 4. szám 80-114. 
következtetésekkel: A társadalomban igény van arra, hogy a magasabb társadalmi státuszú gyereket magasabb társadalmi státuszú pedagógus oktassa, ami ütközik az alacsony státuszú gyermekek érdekeivel. A kisegítő iskola szelep arra, hogy az általános iskolák megszabaduljanak azoktól az alacsony státuszú diákoktól, akik zavarják azt az iskolát, amibe nem illeszkednek bele. Ennek oka abban keresendő, hogy fontosabb néhány tehetség felmutatása, mint a hátrányos helyzetủek szinten tartása, felzárkóztatása, vagy a kudarcoktól való megmentése.

Vári Zsuzsának a Tanácstalan tanácsadók címü írása is csak „rébuszokban” beszélt, amennyiben arról értekezett, hogy a nevelési tanácsadás rendszere miként ütközik az oktatási és gyermekvédelmi rendszer (iskola, gyámügyi hivatal, minisztérium) azon eltérö érdekeivel, amely mindenáron a problémás gyermekek ügyeinek adminisztratív elsimítását és a diszkriminációt várják el tőle.

Ez az írás nagy port kavart, amennyiben három szerző (Hoffmann Gertrúd, Horányi Györgyné, András Tivadar) válaszreakcióit is kiváltotta. Hoffmann Gertrúd és Horányi Györgyné külön-külön is kifogásolta Vári Zsuzsának azon elképzelését, hogy a nevelési tanácsadórendszer egy pusztán gyermekpszichoterápiás intézmény legyen, s kirekessze azon gyermekeket, akiket a családi vagy iskolai környezet veszélyeztet azon indoknál fogva, hogy nem a gyermek sérült, hanem a környezet ellenséges.

A cigánykérdés etnikus megközelítését preferáló Várnagy Elemér Nyelvek, írásbeli hagyományok nélkül címmel írt egy olyan londoni konferenciáról, amelyen a különböző nyelvek írásbeliségéről tanácskoztak. A rendezvényen B.Pongrácz Éva, Várnagy Elemér vett részt Magyarországról, illetve felolvasták Szegő László állásfoglalását.

Szegő szerint a közép-európai roma nyelvjárások történeti fejlődése (az irodalmi törekvések, a nyelvjárások közeledése) felveti a közös írásbeliség és helyesírás szükségességét. Míg B.Pongrácz Éva és Várnagy Elemér a beás gyermekek körében végzett kísérleteikről beszéltek - nemzetközi színtéren is - levonva azt a konzekvenciát, hogy képzőmüvészeti tevékenységgel, néptánccal és színjátszással lehet fejleszteni a beás tanulók beszédkészségét, amire azért van szükség, mert nem rendelkeznek nyelvi kultúrával annak okán, hogy nyelvváltáson mentek keresztuil. B.Pongrácz Éva és Várnagy Elemér ez utóbbi állásfoglalása - már 1984-ben is -

REGIO 23. évf. (2015) 4. szám 80-114. 
megkérdőjelezhető volt, mert a bolgár és a román közösségekröl is elmondható, hogy megváltozott a nyelvük, mégsem „vádolta” soha senki öket azzal, hogy nem rendelkeznek megfelelö nyelvi kulturáltsággal.

A roma nyelvi tematika más formában is szóba került 1984-ben. Szegő László Képes szótár cigány nyelven címü írásában Karsai Ervin és Rostás-Farkas György Kenyva kiponca - Képes szótár címü tankönyvét elemezte, illetve kritizálta annak pedagógiai hiányosságai miatt. Ugyanakkor Szegő írása kiváltotta Vekerdi Tamás válaszát is, aki messzemenően nem értett egyet Szegő Lászlóval, azokban a romákra vonatkozó - demográfiai és nyelvi adatokban, amelyek korábban a Képes szótár cigány nyelven címü írásban jelentek meg.

Ebben az évben továbbra sem volt változás a tekintetben, hogy a roma gyermekeket szegregálni kell-e vagy integrálni. Születtek olyan írások, amelyek a szegregációt részesítették előnyben (Gyermekvédelem Zala megyében, Postánkból), voltak olyan cikkek, amelyek a szegregáció és az integráció közötti ingadozást ábrázolták (Novák Gábor: A közoktatás múltja és jelene Szabolcs-Szatmár megyében - Beszélgetés dr.Kuknyó Jánossal a megyei tanács müvelödési osztályának vezetőjével, Bárdos Deák Béláné: A tankötelezettség statisztikája), de egyetlen olyan írás sem volt, amely az integrációt preferálta volna, miközben azért születtek olyan írások is, amelyek visszautasították a romák etnikus megközelítését azáltal, hogy szociális szempontok mentén elemezték a cigányok problémáit.

Ez utóbbi kategóriába tartozik Csabay Lászlónénak - a Müvelődési Minisztérium Gyógypedagógiai Csoportjának vezetőjének - A gyógypedagógiai nevelés eredményei és feladatai címü írása, amely kategorikusan kijelenti, hogy kisegítő vagy foglalkoztató iskolába csak olyan gyermek kerülhet, akinek idegrendszeri károsodásra visszavezethető problémái vannak a tanulás során, s ezen az állásponton nem is hajlandó változtatni. Konkrétan kimondja: az elmaradott vagy eltérő szociokulturális környezetböl érkezö, retardált, nyelvi nehézséggel küzdö gyermekek felzárkóztatása, fejlesztése nem a kisegítő iskolák feladata, s éppen ezért azt is kifogásolta, hogy a cigány gyerekeknek magas az aránya a kisegítő iskolákban.

A közoktatás fejlesztési programja - Javaslat az öszi nevelési értekezlet tematikájához címú írás is azt javasolta a kisegítő

REGIO 23. évf. (2015) 4. szám 80-114. 
iskoláknak, hogy a nevelőtestületek vitassák meg, hogy milyen helyi tényezők okozzák az iskola azon funkciózavarát, hogy a cigány gyermekek túlreprezentáltak az oktatási intézmény diákjainak körében.

Végül két írást érdemes még megemlíteni 1984-böl. Forray R. Katalin Eredmények és problémák az osztrák oktatásban címü írása szerint a romák nem jelentenek problémát az ausztriai oktatási rendszerben, mert számuk elenyésző. Az igaz, hogy a szülők építőmunkások, dunai hajósok, ezért a cigány gyermekek sokszor nem tudnak iskolába járni, mégsem vetődnek fel komolyan problémák, ugyanis az osztrák oktatási rendszerben megengedett az, hogy két évig osztályozás nélkül tanítsanak az iskolák, s hogy az ismeretszintről vizsgák formájában győződjenek meg.

Köpeczi Béla Az eredményekben kitüntetett szerepük volt a sok nehézséggel küzdö pedagógusoknak, akiknek támogatása, presztízsnövelése, megbecsülése egyik legföbb feladatunk címü írásában - a politika oldaláról - kifogásolta a kisegítő és gyógypedagógiai intézményhálózat elégtelenségét, a cigány származású és hátrányos helyzetű diákok indokolatlan módon kisegítő iskolába történő áthelyezését.

Összegezve az 1984-es évet az állapítható meg, hogy az országban továbbra is egyszerre volt jelen a cigánykérdés etnikus és szociális megközelítése. A hatalom a cigánykérdés pedagógiai vonatkozásait inkább szociális szempontok mentén közelítette meg, miközben az oktatási és nevelési rendszer helyi alkalmazottai, kutatói és irányítói nem egyszer az etnicizálás mellett foglaltak állást gyakorlati lépéseikkel. Az integrációs elképzelések szinte fel sem merültek, a szegregációs koncepciók viszont annál inkább. Ugyanakkor a kapcsolódó írásokból határozottan érzékelhető az is, hogy volt egy olyan értelmiségi réteg is 1984-ben, amely próbálta deetnicizálni a roma ügyet azáltal, hogy a hátrányos helyzetủek tágabb fogalomkörén belül tárgyalta a cigányok problémáit.

1984-ben megtapasztalható volt az is, hogy a roma gyermekek gondjai nyomást gyakoroltak a magyarországi oktatási és nevelési rendszerre, amelynek nyomán a szakma képviselöi között elindult egy olyan vita, amely a tanulási nehézséggel küszködők helyzetének rendezését akarta elérni úgy, hogy közben nem mondták ki: ez utóbbiak alatt sok esetben a roma diákokat értik.

REGIO 23. évf. (2015) 4. szám 80-114. 
1985

1985-ben újfent 22 írás foglalkozott valamilyen vonatkozásban a roma gyermekek oktatásával az alábbi kategóriák szerint:

\begin{tabular}{|c|c|}
\hline a roma tematika negligálása-modell & \\
\hline asszimiláció-modell & \\
\hline integráció-modell & 1 \\
\hline szegregáció-modell & \\
\hline $\begin{array}{l}\text { a cigánykérdés etnikus kérdésként való } \\
\text { felfogása-modell }\end{array}$ & \\
\hline $\begin{array}{l}\text { a cigánykérdés szociális kérdésként való } \\
\text { felfogása-modell }\end{array}$ & \\
\hline $\begin{array}{l}\text { asszimiláció-modell }- \text { a cigánykérdés } \\
\text { etnikus kérdésként való felfogása-modell }\end{array}$ & \\
\hline $\begin{array}{l}\text { szegregáció-modell }- \text { a cigánykérdés } \\
\text { etnikus kérdésként való felfogása-modell }\end{array}$ & 2 \\
\hline $\begin{array}{l}\text { a cigánykérdés etnikus kérdésként való } \\
\text { felfogása-modell - a cigánykérdés szociális } \\
\text { kérdésként való felfogása-modell }\end{array}$ & 1 \\
\hline $\begin{array}{l}\text { integráció-modell }- \text { a cigánykérdés } \\
\text { szociális kérdésként való felfogása modell }\end{array}$ & \\
\hline $\begin{array}{l}\text { integráció modell }- \text { a cigánykérdés } \\
\text { etnikus kérdésként való felfogása-modell }\end{array}$ & 1 \\
\hline multikulturalizmus-modell & \\
\hline integrációs-szegregációs modell & \\
\hline $\begin{array}{l}\text { integrációs-szegregációs modell }- \text { a } \\
\text { cigánykérdés szociális kérdésként való } \\
\text { felfogása-modell }\end{array}$ & \\
\hline $\begin{array}{l}\text { integrációs-szegregációs modell }- \text { a } \\
\text { cigánykérdés etnikus kérdésként való } \\
\text { felfogása-modell }\end{array}$ & \\
\hline roma gyermekekről szóló hír & 4 \\
\hline roma gyermekekről szóló riport & \\
\hline roma gyermekekről szóló helyzetképadás & \\
\hline $\begin{array}{lrr}\begin{array}{l}\text { roma } \\
\text { információkat } \\
\text { tanulmány }\end{array} & \begin{array}{r}\text { gyermekekre } \\
\text { tartalmazó }\end{array} & \begin{array}{r}\text { vonatkozó } \\
\text { publicisztika, }\end{array} \\
\end{array}$ & 7 \\
\hline $\begin{array}{l}\text { roma gyermekekre vonatkozó részek } \\
\text { politikusi megnyilatkozásokban }\end{array}$ & \\
\hline kapcsolódó írás & 1 \\
\hline helyesbítés & \\
\hline szemle & 2 \\
\hline portré & \\
\hline
\end{tabular}

REGIO 23. évf. (2015) 4. szám 80-114. 
novella

módszertani írás

egyéb

összesen:

3

22

A tárgyalt évben ismét be kellett vezetni egy újabb minősítő kategóriát (integráció modell - a a cigánykérdés etnikus kérdésként való felfogása-modell), s azt is le kell szögezni, hogy a Köznevelés hasábjain kevesebb figyelmet fordítottak a szerzők arra, hogy miként kell hatékonyan foglalkozni a roma gyermekekkel, még akkor is, ha 1984-ben szintén 22 írás hozható kapcsolatba a roma tematikával.

Míg 1984-ben a kapcsolódó írások kaptak kiemeltebb szerepet, addig 1985-ben a helyzetképadások voltak jellemzőek. Összesen 4 esetben jelentek meg hírek roma gyermekekkel kapcsolatosan, és 7 esetben jelentek meg olyan írások, amelyek a cigány tanulók oktatásával összefüggően közöltek adatokat.

A hírekből a Köznevelés olvasói arról értesülhettek, hogy Békés megyében tízezer cigány él, akik közül 1850 az általános iskoláskorú, mégis a 45 százalékuk nem fejezi be a nyolc osztályt, így Békésben az az elsődleges törekvés, hogy a roma gyermekek minél nagyobb hányada jusson óvodába és iskolai előkészítőbe.

Az oktatási hetilap hírt adott arról is, hogy Kunmadarason havonta kétszer klubfoglalkozást tartanak a roma gyermekeknek, amelynek keretében mesét és zenét hallgatnak, valamint elsajátítják a diákok a számolás és az egészségügyi tudnivalók alapjait.

1985 júniusában az érdeklődők azt tudhatták meg, hogy Országos Cigány Tanács alakult Budapesten, amely a Hazafias Népfront országos elnöksége mellett fog müködni, s hatókörébe tartoznak a cigány gyermekek oktatásának kérdései, a beilleszkedési gondok, a nyelvi hátrányok leküzdése az iskola kezdő szakaszában.

Az adatközlő írások közül Novák Gábor $A$ büntetés és a nevelés kapcsolata ügyészi szemmel címü írását érdemes kiemelni, amely szerint a gyermekvédelmi felelösöknek a leggyakrabban az állami gondozott és a cigány gyermekek okoznak gondot. Az írás kifejezetten azt állította, hogy az erőszakos büncselekmények 60-70 százalékát roma gyermekek követik el.

Házi Lajos Milyenek a nevelöintézetek? címü írása is arról értekezett - többek között -, hogy a cigány gyerekek körében gyakori az erőszakos büncselekmény, emiatt a javítóintézetes fiataloknak csaknem fele: roma.

REGIO 23. évf. (2015) 4. szám 80-114. 
Novák István és Soós Jánosné A gyógypedagógiai oktatás helyzete Pest megyében címü írásából az derült ki, hogy Pest megyében a kisegíto iskolás tanulók 28 százaléka roma származású, míg a Többen kapnak nevelési segélyt - A gyermekvédelem adatai címü cikk azt tudatta, hogy 116 nevelőotthon 12.835 gyermekének a 45,5 százaléka cigány, illetve 7 nevelőotthon 1023 fiatalkorújának 45,3 százaléka roma.

Vati Papp Ferenc Bicska helyett számítógép címü írása - sok minden egyéb mellett - azt említette meg, hogy Karádon évröl évre nő a veszélyeztetett tanulók száma, akik ráadásul döntő többségében cigányok.

Kerekes László Tanév eleji információk - Az általános iskoláról címet viselő cikkéből az is kiderült, hogy a rendelkezésre álló adatok szerint 200-nál több olyan iskola volt az országban, amely sok hátrányos helyzetü és veszélyeztetett tanulóval küszködött, köztük rengeteg roma gyermekkel, miközben a képesített pedagógusok száma elenyésző volt.

$\mathrm{Az}$ írás szerint a roma gyermekek beóvodáztatása nem volt kielégítő, pedig nekik és a halmozottan hátrányos helyzetü gyermekeknek az hozta volna meg a legnagyobb sikert. Az írás megállapította azt is, hogy tenni kell azért, ha azt akarják, hogy a roma szülők elzárkózását feloldják.

Kerekes írt arról, hogy a cigány gyerekek esetében a tanfolyami felkészítés nem elegendő a sok hiányzás, a fejlesztő programok és alkalmazások hiánya, a nem meg felelő taneszköz, a kidolgozatlan módszertan és a pedagógusok nem kellő felkészültsége miatt.

Csabay Lászlónénak Tanév eleji információ - A gyógypedagógiai nevelés címü írásából az vált nyilvánvalóvá, hogy 1985-ben a kisegítő iskolák tanulói között a cigányok 39,5 százalékos arányt képviseltek.

A tárgyalt évben az egyéb kategóriában szerepelt úti beszámoló, visszaemlékezés és olvasói levél is. Az úti beszámoló Várnagy Elemér tollából született Spanyolország - Látogatás az eldai cigánytelep iskolájában címmel. Ebben az írásban Várnagy arról számolt be, hogy milyen a spanyolországi romák helyzete szervezeti, kulturális, politikai és oktatási tekintetben. Több szempontból úgy vélte, hogy Magyarországon a cigányság ügyének kezelése elörehaladottabb állapotban van (beiskolázás, óvodai elhelyezés, iskola befejezésének mértéke fokozatosan emelkedik, analfabetizmus

REGIO 23. évf. (2015) 4. szám 80-114. 
felszámolása). Ugyanakkor - véleménye szerint - a spanyol romáknak több beleszólása van a saját ügyeik intézésébe. Várnagy szerint Eldában szegregált oktatás folyik, amelynek keretében 6-16 éves diákokat együtt tanítanak, s maga a helyi pedagógus is úgy minősítette a szituációt, hogy az tarthatatlan, amennyiben emberfeletti munkát kell végezni, mivel a tanulók többsége túlkoros, az államtól pedig minimális anyagi segítség érkezik. Várnagy Elemér elhatárolódott úti beszámolójában attól az elóítéletrendszertől, ami a spanyolokban a 40 éves diktatúra alatt alakult ki.

Horváth Béláné Dudus címü visszaemlékezése egy roma kisfiúról szólt, aki 12 évesen is másodikos volt, rengeteg tanulásbeli és tudásbeli hátránnyal. Pedagógusa személyiségközpontú pedagógiai eljárással és egyénre szabott tanulási ütemmel 1 év alatt elérte azt, hogy Rezső ismerte az összes betüt és a számokat, megtanult - még ha verejtékezve is - olvasni, míg végül tollbamondás után is tudott írni. A gyermek közben fokozatosan beilleszkedett az osztályközösségbe, természetbeni segítséget kapott az osztálytársaitól, akiknek a megbecsülését is kivívta teljesítményével annak ellenére, hogy kezdetben rendkívül rossz híre volt.

Dömötör István Ebéd és tanulás címü olvasói levele Csontos Magdának a Köznevelés 1985/2. számában megjelent, Kedvezmények és a nagycsaládok címü írására reagált. Dömötör Csontos Magdához hasonlóan úgy vélte, hogy a hivatalnokok csak kipipálandó feladatnak tartják a több gyermek okozta anyagi hátrány kompenzálására szánt központi összegek elosztását. Dömötör szerint a nagycsaládosok helyzete ennél speciálisabb, ezért differenciálni kellene, s nem rutinszerüen dönteni. A szerző szerint az ő falujában a tanács évente 25 roma tanuló ingyenes étkeztetését vállalta, ha a szülők beíratják gyermekeiket a napközibe, de ezzel a lehetőséggel csak 2-3 cigány család élt, miközben a felelösebben gondolkodó roma családok nem vehetik igénybe ezt a lehetőséget. Szerinte az 50es, 60-as években volt szokás, hogy a jó tanuló diák ingyenesen mehetett napközibe, ami nem csak segítség, de elismerés is volt, s ez legalább olyan fontos, mint a pénz.

Andorka Rudolf $A z$ iskolai oktatás szerepe a modern társadalomban címü írása általánosságban tárgyalta a társadalmi hátrányokat, a különbségek okait, az öröklés vagy nevelés vitáját az IQ-témakörében, a kisegítő iskolákat, az iskolai élet szociológiai problémáit és a diákéletet. Ezen kontextusokban szó esett arról, hogy

REGIO 23. évf. (2015) 4. szám 80-114. 
a cigány anyanyelvüség hátrányt jelent az iskolai előmenetelben, még akkor is, ha nem tudjuk, hogy ez milyen mértékü, mert hogy nincs adat arról, pontosan hányan érintettek ebben a tárgykörben. Andorka Rudolf - Ferge Zsuzsára és Gazsó Ferencre hivatkozva azt állította, hogy a hazai oktatási rendszer növeli az egyenlőtlenségeket, s ennek az az oka, hogy az oktatási rendszer értékelő rendszere csak egy társadalmi réteget képvisel, s az nem a hátrányos helyzetüeké. A cikk felvetette, hogy egyesek szerint a hátrányos helyzetü családok gyermekei genetikai öröklődés miatt alacsonyabb intelligenciával rendelkeznek, míg mások szerint ez nem igaz. Ez a vita Magyarországon a kisegítő iskolák kapcsán bontakozott ki. Czeizel Endre szerint a fogyatékosok a fogyatékosságukat többségükben örökölték, éppen ezért az nem lehet kulturális eredetü. Az aggasztóan megnövekedett szám annak köszönhető, hogy az alacsony intelligenciájú szülöknek az átlagnál több gyermekük születik. Ladányi és Csanádi szerint viszont a kisegítő iskolába kerülést a szülök társadalmi helyzete szabja meg. Sokkal több olyan gyerek van benn, akinek a szülei szakképzetlenek, mint inkább szellemiek, tehát nem csak az IQ-tól függ a bekerülés. Andorka szerint nincs adat az átlagosnál alacsonyabb intelligenciájú gyerekek arányának növekedéséről, inkább arról van szó, hogy a kisegítő iskolai helyek száma nőtt. Budapesten pedig kimutatták, az IQ alapján egyre több esetben nem volt alapos indok a kisegítö iskolai elhelyezésre. Az iskolai végzettség szerinti gyermekszámkülönbség lecsökkent aránya miatt nincs értelme az alacsony iskolai végzettségü réteg különösebben bővülő újratermeléséről beszélni, ami nem jelenti azt, hogy a fogyatékosság kérdésével nem kell foglalkozni, vagy az alacsony müveltségü családok gyermekeivel, ugyanis ez pont azt jelenti, hogy az ilyen családok fokozott szociálpolitikai figyelmet igényelnek.

Gyarmati Szabó Éva Helyzetek és helyzetrajzok címü szemléjében két könyvet mutatott be. Az egyik R. Székely Julianna Aki bújt, aki nem címü kötete (karrier-és sikertörténetek elbukottakról és önmegvalósítókról) volt, a másik Diósi Ágnes Hetedíziglen címü munkája.

Diósi Ágnes bủnöző cigány fiatalokról írt, akikről kiderült, hogy szociokulturálisan elmaradottak, mert halmozottan hátrányos helyzetük vagy a családjuk miatt kerültek a lejtöre. Loránd Ferenc megkérdezte a kötet előszavában, hogy ki azért a felelős, hogy a

REGIO 23. évf. (2015) 4. szám 80-114. 
szóban forgó családok képtelenek a felemelkedésre, s nem mentik meg ezeket a gyermekeket, akik végül hetedíziglen ugyanolyan apák lesznek, mint elődeik. Felelős az iskola, mert csak a tanulási eredményt nézi. A börtön, ami nem nevelöintézmény, hanem a társadalom kétségbeesett védekezése. Diósi azt sugallja: talán az iskola is hatékonyabb lenne más szemléletmóddal - és Gyarmati is hozzáteszi, kár, hogy nem esik szó azokról, akik másképp gondolkodnak, tanítanak, nevelnek.

Rácz-Székely Győző Első folyóiratunk, a Tudományos Gyüjtemény című írása arról az érdekes tényről tudósított, hogy az 1841-ben megszünt lap cigányokról szóló tanulmányok közlését is vállalta.

1985-ben az integráció-modellt Pethő Ágnes Az óvodai nevelömunka címü írása preferálta egyedül, amennyiben azzal foglalkozott, hogy a hátrányos helyzetü és veszélyeztetett gyermekek esetében az 1 éves fejlesztés nem elég, 3 éves beóvodáztatásukra van szükség, s hogy ez mennyire így van, az a cigány gyerekeknél látszik is, mert a roma óvodások száma nőtt és természetes módon integrálódtak bele az óvodai közösségekbe.

Tibor Klára Jó szerencsét, pécsszabolcsiak! - Egy állami díjas pedagógiai mühely címü írása azt mutatta be, hogy Pécsszabolcson hogyan történt az általános iskolai oktatás. Az többször is kiderül a cikkböl, hogy körülbelül a tanulók 20\%-a cigány, azaz integrált környezetben tanultak, ugyanakkor a roma diákok környezetét elöítéletesen ábrázolta. Határozottan az bontakozott ki az írásból, hogy a hanyag romák a gyermekeiket otthon nem tanították meg mosakodni, késsel, villával enni és magyarul beszélni vagy napközibe járatni, ellenben a jóindulatú iskola ezeket a problémákat sikeresen felvállalta. Az írásban Tibor Klára meg sem próbált a dolgok mögé nézni. Nem világított rá arra, hogy abban az esetben, ha a többségi társadalom kirekeszt egy kisebbséget, az olyan szociális elmaradottságot okoz nála, amely nem teszi lehetővé - a többségnek természetes - mosakodási szokásokat, evőeszköz-használatot vagy a napközi megfizetését. $\mathrm{Az}$ is szemet bántó megfogalmazása a szerzőnek, hogy Pécsszabolcson olyan oktatási formát kerestek, ami helyettesíti az otthont és a szülöket, ugyanis az eszébe sem jutott az állami díjas pedagógiai mühelynek, hogy a tanintézménynek a családot kiegészítenie kell, és nem helyettesítenie. Az viszont pozitívum az írásban, hogy a kiégett pedagógusokat alkalmazó

REGIO 23. évf. (2015) 4. szám 80-114. 
napközi helyett iskolaotthont alakítottak ki, ahol ugyanaz a pedagógus gondozta a diákokat, aki délelött is feladta a házi feladatot, míg felső tagozaton nem kötelező klubnapközit alakítottak ki, ahová a diákok 98 százaléka így önként járt el, s ennek eredményeképpen míg 1969-ben 17,5 százalék volt a bukottak aránya, 1985-ben már csak 2,5 százalék.

Speidl Zoltán Cigánygyerekek állami díjas tanítója, illetve Farkas Kálmán Lina címü írásai egy nem roma tanítónő (Csányi Dezsőné), és egy roma óvónő (Rézmüves Mihályné), munkásságát mutatta be. Mindkét esetben az derült ki, hogy a roma gyermekeket lepusztult, szegregált környezetben is lehet eredményesen tanítani, ha a roma sajátosságokra építenek a pedagógusok.

Végül Andorka Rudolf Az életmód címủ írását érdemes kiemelni, amelyben arról értekezett, hogy miközben a közvélemény szerint a cigányok életmódja lényegesen eltér a nem romákétól, aközben ezt Kemény István 1971-es cigányságvizsgálata nem igazolta vissza, ugyanakkor Szakolczai Árpád és Hankiss Elemér arra a megállapításra jutott, hogy a romák értékválasztása valóban elüt a nem romákétól.

Összegezve az 1985-ös évet az állapítható meg, hogy az írások 50\%-a híradás és adatközlés volt, amelyekből többnyire az derült ki, hogy milyen sok probléma van a cigány gyermekekkel az óvodákban, az általános iskolákban, a kisegítő iskolákban, a nevelöotthonokban. Rendszeresen szóba került az, hogy a roma tanulók bünözők és veszélyeztető környezetben élnek. A szüleik pedig hanyagok, mert nem tanítják meg őket késsel és villával enni vagy mosakodni, vagy csak nemes egyszerüséggel nem járatják őket napközibe.

1985-ben olyan mértékben uralkodott el az etnikus szemlélet a Köznevelés hasábjain, hogy szinte teljesen perifériára szorították az egyéb írásokat. Még az integrált oktatást preferáló írásban is (Tibor Klára Jó szerencsét, pécsszabolcsiak! - Egy állami díjas pedagógiai mühely) hemzsegnek az elöítéletek, pedig az integráció-modell általában a cigánykérdés szociális alapú megközelítésével szokott együtt járni.

Az oktatási rendszer halk szavú - szociális szempontú kritikáját Gyarmati Szabó Éva képviselte Diósi Ágnes munkájának ismertetésével, valamint Horváth Béláné az általa megvalósított személyiségközpontú pedagógiával.

REGIO 23. évf. (2015) 4. szám 80-114. 
S persze nem lehet elmenni szó nélkül amellett sem, hogy Andorka Rudolf Az iskolai oktatás szerepe a modern társadalomban címü írása szerint - a kisegítő iskolák kapcsán - már genetikai okokat is megpróbáltak felsorakoztatni, ismét a nyilvánvaló szociális és szociokulturális hátrányok ellenében, amely a legvadabb elképzeléseket is felülmúlja egy pedagógiai szaklap hasábjain.

\section{6}

1986-ban mérséklődött az érdeklődés a roma tematika iránt, amennyiben mindösszesen 15 írás jelent meg a következő kategóriákban:

\begin{tabular}{|c|c|}
\hline a roma tematika negligálása-modell & \\
\hline asszimiláció-modell & \\
\hline integráció-modell & \\
\hline szegregáció-modell & \\
\hline $\begin{array}{c}\text { a cigánykérdés etnikus kérdésként való } \\
\text { felfogása-modell }\end{array}$ & \\
\hline $\begin{array}{c}\text { a cigánykérdés szociális kérdésként való } \\
\text { felfogása-modell }\end{array}$ & \\
\hline $\begin{array}{c}\text { asszimiláció-modell - a cigánykérdés } \\
\text { etnikus kérdésként való felfogása-modell }\end{array}$ & \\
\hline $\begin{array}{c}\text { szegregáció-modell - a cigánykérdés } \\
\text { etnikus kérdésként való felfogása-modell }\end{array}$ & \\
\hline $\begin{array}{c}\text { a cigánykérdés etnikus kérdésként való } \\
\text { felfogása-modell - cigánykérdés szociális } \\
\text { kérdésként való felfogása-modell }\end{array}$ & \\
\hline $\begin{array}{c}\text { integráció-modell - a cigánykérdés } \\
\text { szociális kérdésként való felfogása-modell }\end{array}$ & \\
\hline $\begin{array}{c}\text { integráció modell - a cigánykérdés } \\
\text { etnikus kérdésként való felfogása-modell }\end{array}$ & \\
\hline multikulturalizmus-modell & \\
\hline $\begin{array}{c}\text { integrációs-szegregációs modell } \\
\text { integrációs-szegregációs modell - a } \\
\text { szociális kérdésként való }\end{array}$ & \\
\hline $\begin{array}{c}\text { cigánykérdés } \\
\text { felfogása-modell }\end{array}$ & \\
\hline $\begin{array}{c}\text { integrációs-szegregációs modell - a } \\
\text { cigánykérdés etnikus kérdésként való } \\
\text { felfogása-modell }\end{array}$ & \\
\hline roma gyermekekröl szóló hír & \\
\hline roma gyermekekröl szóló riport & \\
\hline
\end{tabular}

REGIO 23. évf. (2015) 4. szám 80-114. 


\begin{tabular}{|c|c|}
\hline roma gyermekekröl szóló helyzetképadás & \\
\hline 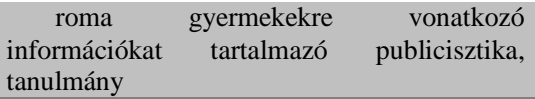 & 2 \\
\hline $\begin{array}{l}\text { roma gyermekekre vonatkozó részek } \\
\text { politikusi megnyilatkozásokban }\end{array}$ & \\
\hline kapcsolódó írás & 1 \\
\hline helyesbítés & \\
\hline szemle & 1 \\
\hline portré & \\
\hline novella & \\
\hline módszertani írás & \\
\hline $\begin{array}{l}\text { egyéb } \\
\text { összesen: }\end{array}$ & 2 \\
\hline
\end{tabular}

Az 1986-os évben szintén kiemelkedő helyet foglaltak el az információkat nyújtó írások. A 15 cikknek majdnem az egyharmada volt besorolható a hírek kategóriába, s ezen rovaton belül az oktatáspolitikai hetilap olvasói értesülhettek Baranya megye roma vonatkozású óvodáztatási és iskoláztatási adatairól, a Zsigó Jenő által rendezett - Kozák téri cigány gyermekklubhoz köthető - kulturális (müsoros) eströl, a Szabolcs-Szatmár Megye Tanácsa által a középfokú oktatásban tanuló roma tanulók számára felajánlott ösztöndíjazási lehetőségekröl és a Pest Megyei Cigány Közművelődési Napokról.

Az adatközlö írásokból (Somogy megye közoktatásáról, Speidl Zoltán: Százegy általános iskola felemelése) százalékos adatokat tudhatott meg Somogy megye - a cigány tanulókat érintö gyógypedagógiai, állami gondozásbeli, általános iskolai jellemzőiről, valamint Borsod-Abaúj-Zemplén, Szabolcs-Szatmár-Bereg, Nógrád és Pest megyék roma tanulóinak iskolai arányáról, $\mathrm{s}$ az is kiderült, hogy a veszélyeztetett tanulók nagy száma és a cigány tanulók jelentős aránya között csak Borsod-Abaúj-Zemplén, SzabolcsSzatmár-Bereg és Pest megyékben van összefüggés.

1986-ban csak egy kapcsolódó írás született Marg Csapó tollából Elkülönítés nélküli gyógypedagógiai nevelés Kanadában címmel, amelyben a szerző megfogalmazta azt, hogy az 1960-as években itt hasonlóképpen küszködtek azzal, hogy a gyógypedagógiai intézmények szegregálták a fogyatékos, vak vagy siket gyermekeket, ami miatt végül úgy döntöttek, hogy az egész intézményrendszert integrálják a normál oktatási rendszerbe. Az írásban Marg Csapó

REGIO 23. évf. (2015) 4. szám 80-114. 
részletesen kitért arra, hogy az oktatási reform során mitől féltek a gyógypedagógusok, az egészséges gyermekek és a gyógypedagógiai ellátására szoruló diákok szülei, s azt is leírta, hogy ezekre milyen gyakorlati válaszokat adtak, amelyek feloldották a feszültséget mindenkiben és eredményessé tették az új oktatási rendszert. Marg Csapó alaptézise az, hogy szegregált körülmények között nem lehet senkit sem felkészíteni arra, hogy egy integrált munkaeröpiaci környezetben és társadalomban megállja a helyét, ezért az integrált nevelésnek a híve, és kifogásolja azt is, hogy Magyarországon a roma népesség arányához képest a cigány gyerekek felülreprezentáltak a kisegítő iskolákban. Szerinte hazánkban sokkal kisebb esélye van annak, hogy értelmiségi szülő gyermeke kerül a gyógypedagógiai intézménybe, mint annak, hogy kevéssé szakképzett munkásoké.

1986-ban megjelent 3 olyan szakcikk is, amely szociális alapon fogalmazta meg a téziseit a cigány gyermekek iskoláztatásával kapcsolatban és elutasította a diszkrimináció legenyhébb formáját is. Az egyik ilyen írás Csabay Lászlóné tollából született $A$ megújuló gyógypedagógia - Az áthelyezési bizottságok müködésének tapasztalatai címmel. A Művelődési Minisztérium Gyógypedagógiai Csoportjának vezetője azt kifogásolta, hogy 1986-ra a kisegítő iskolákba áthelyezett gyermekek összlétszámán belül 39-ről 39,7 százalékra nőtt a roma gyermekek aránya. A szerző szerint a vonatkozó általános iskolai javaslatok és a szakvélemények túlnyomó többsége téves, ugyanis semmi sem igazolja azt, hogy a cigány lakosságon belül az átlagosnál több - értelmi fogyatékosságot előidéző - genetikai ártalom lenne. Szerinte a roma tanulók tekintélyes része nem szorul gyógypedagógiai ellátásra, mert a problémáik megoldhatók lennének korrekciós osztályokban való oktatással vagy több egyéni foglalkozással.

Bánfalvy Csaba és Bass László Ki kerül kisegitő iskolába? címü írása is hasonló kérdéseket feszeget. Egy Zala megyei kutatás kapcsán megállapítják, hogy sokkal nagyobb eséllyel kerül kisegítő iskolába egy olyan roma gyermek, akinek a családjában alacsony a jövedelem, mint egy olyan nem roma tanuló, aki gyenge képességü (esetleg értelmi fogyatékos), de a családja magasabb státusú. A kutatók azt is megállapították, hogy a cigányok előbb kerülnek áthelyezésre, mint a nem cigányok. S az áthelyezésre javasoltak kétharmada szegény, míg a nem javasoltaknak csak egyharmada.

REGIO 23. évf. (2015) 4. szám 80-114. 
Pedagógusok az áthelyezettek 70\%-ának apjáról állították, hogy alacsony végzettségü, míg azokban az esetekben, ahol nem történt áthelyezés, csak 42\%-ban vélelmezték ugyanezt, miközben a roma és nem roma apák végzettsége között nem volt ennyire szignifikáns különbség. A felmérés szerint olyan gyermekek kerülnek leginkább a kisegítő iskolába, akiket a pedagógusok kulturálisan kevésbé törekvő és deviáns cigánynak minősítenek, alacsony iskolai végzettségü apával. A kutatók szerint a pedagógusok a vizsgált tanulók 10 százalékát (238 fó) akarták áthelyezni kisegítő iskolába úgy, hogy közülük 54 diákot értelmi fogyatékosnak minősítettek. Ezzel szemben az áthelyező bizottság „csak” 139 foót vett fel a listára és 4090 százalékban értett egyet a pedagógusokkal.

Horváth György Péter Európai gondok a cigányság iskoláztatásában címü írása fontos összefoglaló és elemző cikk. A szerző részben áttekintette a romák oktatásának történetét, kitekintést nyújtott az akkori csehszlovákiai iskolai tapasztalatokra, de kitért az Osztrák-Magyar Monarchia és Svédország romák oktatásával kapcsolatos kísérleteire is. Írásán érződik, hogy a szerző megfelelő tudásszinttel rendelkezett a roma tematikát illetően. Pontosan látta hol vannak az oktatási rendszer buktatói, hogy mikor, hol és kik diszkriminálják a cigány tanulókat és miért. Horváth írt arról is, hogy az európai országok egymás után jöttek rá arra, hogy a romák szociális és szociokulturális elmaradottsága miatt más típusú iskolaérettségi kritériumokat kell kidolgozni. Kitért arra, hogy a cigány diákokat sokszor alaptalanul gyógypedagógiai intézményekbe helyezik át, ahol később kiderül róluk, hogy nem károsodottak mentálisán, pusztán a fejlődésükben visszamaradottak. Érintette azt a kérdést is, hogy a gyógypedagógiai intézmények kapcsán sokszor etnikai és örökletes okokra hivatkoznak, pedig szerinte ez indokolatlan, ugyanis többször kiderült, hogy abban az esetben, ha örökbe fogadták őket, vagy a jobb szociális körülményeket biztosító nevelöintézetekbe kerültek, akkor jobb eredményeket értek el, mint azok a roma társaik, akik a rosszabb szociokulturális feltételekkel rendelkező családjukban nőttek fel. Ráadásul egy másik helyen a szerző azt is megjegyezte a cikkében, hogy ahol a roma szülök bérmunkából élnek és az anya is dolgozik, ott a roma diákok érettebben érkeznek az iskolába. Írt az óvodáztatás szükségességéről is, mert szerinte az 1 . osztály követelménye olyan magas, hogy azt a jobban szituált tanulók sem képesek teljesíteni óvodai előképzés

REGIO 23. évf. (2015) 4. szám 80-114. 
nélkül. A hivatkozott cikkben egyedül az kifogásolható, hogy a szerző szerint az iskola a cigány kultúra normáival ellenpólust képez, ugyanis vitatható, hogy a roma közösség a származásából eredően kerül-e szembe az oktatási rendszerrel, vagy azért, mert a kirekesztettsége olyan szociális és szociokulturális elmaradást okoz, amely nem egyeztethető össze az iskola által elvárt szociális és szociokulturális normarendszerrel.

A három utóbbi írásnak ellenpontját képezi Czuczu Tibor (cigány származású szakfelügyelő) öngyülölő vagy inkább felvilágosult rasszista, Mit tegyünk a cigány tanulókért? címü írása. A szerző a differenciálódott roma közösség helyett - általánosító módon - a „lerongyolódott cigány” képét rajzolta meg, aki halmozottan hátrányos helyzetü, ezért kifogásolható a viselkedése, társaival indulatos, ingerlékeny, nem ismeri a helyes baráti kapcsolatokat, a helyes magatartást a felnőttekkel szemben, nincs a következetességhez és a rendhez szokva, figyelme pontatlan, felületes, rövid ideig tartó, ruhája szakadozott, teste maszatos, gondolkodása lassú, sok esetben primitív, ismeretei szűk körre terjednek ki, rosszak a lakáskörülményei, divat a felnőttek körében az alkoholizálás és a rendetlen életmód. Czuczu szerint az ilyen roma gyermeknek létfontosságú az óvodáztatása, de az óvónők bajban vannak, mert az óvoda nem kötelező, a cigány szülőknek pedig kényelmesebb kiengedni a gyereket az utcára, mint megmosdatni, felöltöztetni, tiszta ruhába öltözetni, elkísérni az óvodába és délután érte menni. Czuczu szerint a felemelkedés útja a munka mellett az iskolán át vezet. Ugyanakkor a veszélyeztetett gyermekek 60 százaléka cigány, s arányuk egyre nő, mert otthon nem kielégítő körülmények között élnek. Sokszor többszörös osztályismétlők, mert lakásukban nincs megfelelő lehetőség a tanulásra, ráadásul az sem ritka, hogy 14-15 évesen szülnek.Czuczu szerint a roma tanulókat meg kell tanítani az együttélés szabályaira, az egészségügyi szokásokra, az önkiszolgálásra otthon és az iskolában, valamint a tanszerek rendben tartására. A pedagógusnak a képességeikhez kell igazítani a feladatokat, már tavasztól foglalkozni kell külön azokkal, akik gyengék valamilyen tárgyból, különben megbuknak. Rá kell szoktatni öket, hogy nem csak a kéznek, a padoknak is tisztának kell lenni. Érzékeljék a bizalmat, mert akkor a feladatokat meg tudják oldani. Értékelni kell a legkisebb eredményt is, hogy fokozzák a

REGIO 23. évf. (2015) 4. szám 80-114. 
munkakedvüket. Oldott légkört kell teremteni, ahol nincs éles hatás a játék és a munka között.

Rácz-Székely Győző - szintén etnikus és elöítéletes megközelítést alkalmazó - A szarvasi cigányok címü írása, Dr.Domán Imre - a cikkel azonos címü - kötetét mutatta be. Az derült ki belőle, hogy a szarvasi cigányok lókupecek, a földművelést pedig igyekeznek elkerülni. Koldulnak, adnak-vesznek, felfokozott a szexuális étvágyuk, jó nyelvérzékük van, hatévesen egyformán lenézik a magyarokat és a cigányokat, cigány vajdák és cigány bírók vannak közöttük, de kikerülnek a körükböl muzsikus családok is, miközben a lóimádat még mindig jellemző rájuk.

Végül Vati Papp Ferenc Kudarcok középfokon címü írásáról kell szót ejteni, ami Liskó Ilona - a cikkel azonos címü - kötetét mutatta be. Vati Papp szerint a pedagógusok sokszor olyan gyermekekkel találkoznak, akiknek olyan családi problémákat kell megoldani nap mint nap, amivel a pedagógusok nem is szembesülnek még akkor sem, ha 70-80 évig élnek, éppen ezért az ilyen tanulóknak nem az iskola a legföbb gondjuk. A cikk szerint szociálpszichológiai és iskolaszociológiai kutatások egybehangzóan azt bizonyítják, hogy a középfokú iskolában való sikeres teljesítéshez szükség van egy bizonyos fokú biztonságérzetre is, ugyanis a felmérések azt mutatták, hogy az iskolából kimaradó gyermekek felénél az érzelmi stabilitás hiánya is hozzájárult az iskolai kudarcokhoz.

Liskó Ilona szociológiai tanulmányában 4 kérdést tett fel: 1. Kik maradnak ki az iskolából? 2. Hogyan maradnak ki? 3. Miért maradnak ki? 4. Mi lesz velük? S végül megállapította, hogy esett már ki az oktatási rendszerből miniszterunoka és Kossuth-díjas színész fia is, de a közvélemény ezt nehezebben dolgozza fel, mintha egy falusi kanász vagy egy gyüjtögetésből élő cigány gyereke esik ki.

Összegezve az 1986-ban megjelent írások tartalmát, az a konzekvencia vonható le, hogy ebben az évben erőteljes módon került terítékre a kisegítő iskolába helyezett roma tanulók helyzete, több írásban is - közvetve és közvetlenül - kimondásra került az a tény, hogy miközben a neveléskutatók, oktatási szakértők rendszeresen bírálják a pedagógusok és az áthelyező bizottságok munkáját, szakértelmét, aközben a halmozottan hátrányos helyzetü roma diákokat folyamatosan sújtják az elöítéletek, amelynek áldozatául is esnek, és indokolatlanul kerülnek be egy olyan

REGIO 23. évf. (2015) 4. szám 80-114. 
gyógypedagógiai intézménybe, ahol semmi keresnivalójuk sincs, s amellyel örökre megpecsételik a sorsukat, mert kiszakítják őket egy integrált közösségböl és esélyük nem lesz arra, hogy felkészüljenek az integrált munkaerőpiacon való sikeres szereplésre.

Az írásokból kiderül, hogy azok a szakírók, akik a kisegítő iskolákat kritizálják, valószínüleg jó úton haladnak, mert olyan dolgokat kérdőjeleznek meg, amelyeket negyed századdal korábban Kanadában is kritizáltak az érintett értelmiségiek, s olyan célokkal, amely célokat 1986-ban Magyarországon is megfogalmaztak.

Ebben az évben a roma értelmiségi törekvések ábrázolása is megjelent a Köznevelés hasábjain. A Nyissatok ajtót! címü írás kapcsán az olvasók szembesülhettek Szepesi József és Bari Károly roma költők jelenlétével, Balogh Béla táncmüvész munkásságával, az Ando Drom cigány együttes létezésével, valamint Zsigó Jenő azon rendezői koncepciójával, amely egyszerre mutatta meg, hogy az új cigány értelmiségi réteg hogyan kívánja megjeleníteni önmagát a közbeszédben, s hogy miként viszonyul a tehetséges roma gyermekek azon diszkriminációjához, amelynek során indokolatlanul - kisegítő iskolába utalják őket.

1986-ban mindösszesen 2 írás tárgyalta a roma tematikát etnikus színezetben, amelyek közül az egyik inkább egy romantikus ábrándképet idézett (Rácz-Székely Győző: A szarvasi cigányok), a másik viszont (Czuczu Tibor cigány származású szakfelügyelő írása: Mit tegyünk a cigány tanulókért) tipikus példája annak, hogy egy kisebbségi sorsban élő értelmiségi miként fordul saját közössége ellen.

Czuczu Tibor hivatkozott írása nem vette figyelembe ugyanúgy, mint az 1983-as írásában - azt, hogy már az ö idejében is éltek Magyarországon romungró, beás és oláhcigányok, nem számolt azzal, hogy a beások három alcsoportra oszlottak, hogy az oláhcigányoknak legalább 15-20 alcsoportja volt, hogy az összcigányság társadalmi, gazdasági rétegzettségét és képzettségét tekintve rendkívül heterogén formát öltött. A valós kép helyett - az 1983-as írásához hasonlóan - egyetlen romantikus figurát absztrahált „a cigányként”, és felcímkézte az összes olyan hátránnyal, amely a közbeszédben és a közgondolkodásban részleteiben élt, s miután ezzel „végzett”, a diszkriminációtól sújtott, halmozottan hátrányos helyzetü cigányt megalázta és megbélyegezte minden olyan dologért, amelytől szenvedett. Czuczu Tibor írásai - már nem először -

REGIO 23. évf. (2015) 4. szám 80-114. 
tartalmaztak olyan megjegyzéseket, amelyek dehonesztálóak voltak a romákra, s ez arra utal, hogy a Köznevelés számára nem az volt a fontos, hogy mit és hogyan írtak a cigányokról, hanem az, hogy ki írta. Azaz az oktatási hetilap készítői beleestek abba a hibába, hogy azt képzelték: egy cigány szakíró hitelesebb képet tud nyújtani a romákról, mint egy nem cigány értelmiségi, miközben azt kellett volna tudniuk, hogy egy cikk minőségét nem az író származása határozza meg, hanem a felkészültsége.

\section{7}

1987-ben 28-ra emelkedett azoknak az írásoknak a száma, amelyek közvetlenül vagy közvetve köthetőek voltak a roma tematikához az alábbi kategóriák szerint:

\begin{tabular}{|c|c|}
\hline a roma tematika negligálása-modell & \\
\hline asszimiláció-modell & \\
\hline integráció-modell & \\
\hline szegregáció-modell & 2 \\
\hline $\begin{array}{l}\text { a cigánykérdés etnikus kérdésként való } \\
\text { felfogása-modell }\end{array}$ & 6 \\
\hline $\begin{array}{l}\text { a cigánykérdés szociális kérdésként való } \\
\text { felfogása-modell }\end{array}$ & 1 \\
\hline $\begin{array}{l}\text { asszimiláció-modell - a cigánykérdés } \\
\text { etnikus kérdésként való felfogása-modell }\end{array}$ & \\
\hline $\begin{array}{l}\text { szegregáció-modell }- \text { a cigánykérdés } \\
\text { etnikus kérdésként való felfogása-modell }\end{array}$ & 2 \\
\hline $\begin{array}{l}\text { a cigánykérdés etnikus kérdésként való } \\
\text { felfogása-modell - a cigánykérdés szociális } \\
\text { kérdésként való felfogása-modell }\end{array}$ & 1 \\
\hline $\begin{array}{c}\text { integráció-modell }-\quad \text { cigánykérdés } \\
\text { szociális kérdésként való felfogása modell }\end{array}$ & \\
\hline $\begin{array}{l}\text { integráció modell }- \text { a cigánykérdés } \\
\text { etnikus kérdésként való felfogása-modell }\end{array}$ & \\
\hline multikulturalizmus-modell & \\
\hline integrációs-szegregációs modell & 1 \\
\hline $\begin{array}{l}\text { integrációs-szegregációs modell }- \text { a } \\
\text { cigánykérdés szociális kérdésként való } \\
\text { felfogása-modell }\end{array}$ & \\
\hline $\begin{array}{l}\text { integrációs-szegregációs modell }- \text { a } \\
\text { cigánykérdés etnikus kérdésként való felfogás } \\
\text {-modell }\end{array}$ & \\
\hline roma gyermekekről szóló hír & 1 \\
\hline
\end{tabular}

REGIO 23. évf. (2015) 4. szám 80-114. 


\begin{tabular}{|c|c|}
\hline roma gyermekekről szóló riport & \\
\hline roma gyermekekről szóló helyzetképadás & \\
\hline $\begin{array}{lrr}\begin{array}{c}\text { roma } \\
\text { információkat }\end{array} & \begin{array}{r}\text { gyermekekre } \\
\text { tartalmazó }\end{array} & \begin{array}{r}\text { vonatkozó } \\
\text { publicisztika, }\end{array} \\
\text { tanulmány } & & \end{array}$ & \\
\hline $\begin{array}{l}\text { roma gyermekekre vonatkozó részek } \\
\text { politikusi megnyilatkozásokban }\end{array}$ & 1 \\
\hline kapcsolódó írás & 11 \\
\hline helyesbítés & \\
\hline szemle & \\
\hline portré & \\
\hline novella & \\
\hline módszertani írás & \\
\hline egyéb: & 2 \\
\hline összesen: & 28 \\
\hline
\end{tabular}

Az 1987-es évben az írások egy jelentős része (11 szakcikk) nem közvetlenül foglalkozott a roma gyermekekkel, alig említette meg öket, ugyanakkor az ő sorsukat is jelentősen befolyásoló intézményrendszeri kifogásokkal, átalakítási javaslatokkal foglalkozott, míg a publikációk másik számottevő (8 szakcikk) rétege a cigány tanulók oktatásának problémáit tárgyalta - némely esetekben - nem csak etnikus alapokon, hanem kifejezetten elöítéletes és rasszista attitüddel.

A 11 kapcsolódó írásból fontos kitérni Kronstein Gábor $A z$ általános iskola funkciózavarai című írására, amely Csabay Lászlónét, a Müvelődési Minisztérium Gyógypedagógiai Csoportjának vezetőjét szólaltatta meg. Az írásban rengeteg adat került ismertetésre a gyógypedagógiai intézményrendszerrel kapcsolatosan, amelyek elemzése nem képezi jelen tanulmány célját, de két dolgot fontos kiemelni. Az egyik az, hogy a szaktárca úgy vélte - az elkülönítési törekvésekböl adódóan - 10-12 ezer gyermeket helyeztek át indokolatlanul kisegítő iskolába, ami magas szám, mert a roma gyermekek 12 százaléka tanul ilyen keretek között, a másik pedig az, hogy a Müvelödési Minisztérium alkalmazni fogja a közoktatási törvényben a Ladányi János és Csanádi Gábor által a Szelekció az általános iskolában címü könyvének javaslatait. Ennek nyomán az eltérő mértékben értelmi fogyatékos gyermekek óvodai nevelésének bővítését tervezték és a középfokú oktatásuk megszervezését annak érdekében, hogy lehetőségük legyen továbbtanulni, miközben szándék mutatkozott a

REGIO 23. évf. (2015) 4. szám 80-114. 
kisegítő iskolák tárgyi és személyi feltételeinek javítására is, mert úgy vélték, az lenne a jó, ha az általános iskola eljutna az egyéni bánásmódhoz, ha megszünne az elkülönítö áthelyezés, $\mathrm{s}$ ha a munkahelyek szívesen fogadnák azokat a fiatalokat is, akik gyógypedagógiai iskolát végeztek.

Csabayné azt is kijelentette, hogy felgyorsítják a visszahelyezéseket, mert a hatóság is kevésnek tartja az évenkénti 100-120 visszahelyezést. Ennek érdekében kidolgoztak egy olyan eljárást is, amely féléves és heti ötórás felzárkóztató képzést ír elő.

Csabay Lászlóné Marg Csapó - 1986-ban megjelent Elkülönités nélküli gyógypedagógiai nevelés Kanadában címü írását is lereagálta $A z$ együttnevelés buktatói címmel. A minisztériumi csoportvezető írásából az derült ki, hogy érdeklődéssel olvasta Marg Csapó írását, különös tekintettel arra, hogy Magyarországon is van integrált nevelés, mégis kissé idealisztikusnak tartotta az írását. Csabayné szerint nem lehet elintézni például a vak gyermekek kérdését azzal, hogy „csak” annyi problémájuk van, hogy nem látnak, ugyanis szerinte a kérdés ettől komplexebb. A svéd szakirodalomra hivatkozva azt állítja: nincsenek meggyőző adatok és érvek az integrált oktatás mellett, és Marg Csapó sem sorakoztatott fel ilyen jellegü bizonyítékokat. Csabayné kifogásolja, hogy a kanadai szakíró szembeállította egymással az integráló és az elkülönítő oktatást, mert - szerinte - ezt még azok az országok sem tették meg, ahol nagyon hangsúlyos az integrált nevelés. Csabayné kifogásolta azt is, hogy Marg Csapó szerint Magyarországon nincsen integrált nevelés, ezért ennek cáfolatául áttekintette a hazai oktatási formációk rendszerét.

Volentics Anna Kanada messze van címü írásában szintén lereagálta Marg Csapó állításait, amelynek az a legfőbb üzenete, hogy Magyarország - Kanadával szemben - egy elöítéletekkel teli ország, ahol kirekesztés folyik, s erre bizonyíték az, hogy a roma tanulóknak csak 30-40 százaléka jut el hatodik osztályba, miközben a kisegítő iskolákban is megközelítőleg 40 százalék az arányuk. Volentics Anna szerint jó lenne, ha a hazai oktatási rendszer nem diszkriminálná az ép értelmü, de tanulási és viselkedési zavarral küszködő gyermekeket, de ez nincs így.

A kapcsolódó írások közül külön kiemelkedik Engelmayer Ágnes Az eltérö képességü gyermekek integrált nevelésének pszichológiai feltételei címü írása, amely részletesen áttekintette a 
gyógypedagógiáról és annak gyakorlati alkalmazásáról való gondolkodás történetét, valamint részletes leírást adott arról, hogy hogyan kellene kinéznie egy valóban integratív nevelési és oktatási rendszernek.

Kereszty Zsuzsa Az óvodából az iskolába való átmenet problémái a fejlettség szerinti beiskolázás tükrében címü írása követelte az egyéni bánásmódot, a differenciálást, a képességfejlesztést, valamint azt, hogy az iskolaérettségi vizsgálat roma anyanyelvü hatévesek számára alkalmas változatát dolgozzák ki.

A haladó szellemiségü írásokkal szemben retrográd írások tömkelege is megjelent 1987-ben a Köznevelés hasábjain olyan állításokkal, amelyek ma már nem türnének nyomdafestéket. Ezekre az írásokra általában az volt jellemző, hogy felülröl tekintettek a romákra, a „,vad népre, amelyet megszelídített, vagy megszelídíteni igyekezett, az okos és jóindulatú fehér ember.

Miksa Lajos A cigánygyerekek iskoláztatása Baranyában címü riportja körképet nyújtott Baranya megye cigány tanulóit érintő általános iskolai és gyógypedagógiai képzéséről. Az írásban az olvasók megismerkedhettek Egyházasharaszti és Alsószentmárton helyzetével, s a szakcikk végkicsengése az volt, hogy a nem roma pedagógus értelmiségi réteg, valamint a település vezetői mindent megtettek a lehető legnagyobb jóindulattal és anyagi ráfordítással a romákért, de azoknak egy jelentős része nem együttmüködő, a cigány szülők inkább az elfogadhatatlan magatartást tanúsító gyermekeiket támogatják, mint az oktatási intézmények erőfeszítéseit. Akad példa a korai elhálásra, teherbeesésre. A romák magától értetődőnek tartják a különböző támogatási formákat. A péntekre úgy tekintenek, mint a szabad szombatra, ezért már akkor abbahagyják az iskolalátogatást. Az iskolabuszon a pedagógusoknak elöl, középen és hátul kell helyet foglalniuk, hogy rendet tudjanak tartani a roma tanulók között. De akadnak kis létszámban kivételek is. Vannak középfokú intézményben továbbtanulók, de azoknak a száma igen csekély. Általában - részben a spontán kialakult cigány többség miatt - a diákok szegregált körülmények között tanulnak és a kisegítő iskolában is rendkívül magas a részarányuk.

Varga Sándor bogácsi iskolaigazgató Levelezés rovatban megjelent írása is hasonlóképpen a romákat megbélyegző állásfoglalásokat tett közzé, és a szegregáló oktatási formációkban látta az előrelépés esélyét.

REGIO 23. évf. (2015) 4. szám 80-114. 
Vati Papp Ferenc Visszatekintés egy iskolára címmel Miksa Lajos A cigánygyerekek iskoláztatása Baranyában címü írását reagálta le azzal, hogy olyan pedagógusról adott hírt, aki tetves cigány tanulók fertőtlenítésével foglalkozott reggelenként másfél órán át, valamint beszámolt arról, hogy egy olvasmánya szerint olyan roma tanulóra is van példa, aki nem tudja a színek nevét, csak mutogatni tudja öket.

Molnár Lóránt Ajtót, ablakot tárt a világra - Bemutatjuk Nagy Rudolf györújbaráti nyugdíjas tanitót címü írása azt mutatta be, hogy egy 1957-ben alakult, szegregált, cigány iskolában Nagy Rudolf hogyan hódította meg a roma tanulókat és a cigány lakosságot az oktatási intézménynek heroikus küzdelemmel és sikeresen.

Novák Gábor A megelözés szerepe a gyermekvédelemben címü írásában egy malmöi kongresszusról írt, amely témája az állami gondozásba vétel megelőzését célozta. Ugyanakkor a szakcikkben akadt egy olyan megjegyzés, amely szerint Magyarországon nem sok esély van a családba való visszahelyezésre - a nemzetközi gyakorlattal ellentétben -, mert hazánkban az állami gondozottak fele cigány, és 13-14 évesen már antiszociálisan kerülnek be a rendszerbe, ezért nehéz öket örökbe adni, sőt még a nevelöszülök is óvakodnak tölük.

1987-ben - a szélsőségesen (felvilágosult rasszista módon) fogalmazó írások tekintetében - ismét Czuczu Tibor, acigány származású szakfelügyelő tette fel az i-re a pontot. A cigánygyerekek nevelésének sajátosságai címü írása szerint gondot jelent a cigányok nagy népszaporulata, nem ismerik és nem is akarják ismerni a családtervezést. Ösi hagyományok szerint vállalnak gyereket, vándorösztön hajtja őket egyik munkahelyről a másikra, nagyrészük dolgozik, de csak addig, amíg meg nem kapják a családi pótlékot. Nem csoda, ha sok közöttük a bünöző és az értelmi fogyatékos, ingerszegény környezetben élnek, ezért később érnek, mint a nem cigányok, idegesek, mert a zsúfolt lakásban nem tudják magukat kipihenni, alkoholisták, naponta hangoskodnak és verekednek, veszélyesen élnek, ezért a cigány gyerekben nem alakul ki a biztonságérzet, így nem tud alkalmazkodni az iskolában. A 7-10 éves roma gyermeket nehéz rávenni a szellemi munkára, vegyes osztályban akadályozzák a tanítást, mert csak rájuk kellene koncentrálni a pedagógusnak, így nem jut nekik elég figyelem, pedig az átlagtól több kellene nekik, jó képességüek, ám a tanulmányi

REGIO 23. évf. (2015) 4. szám 80-114. 
eredményeik ezt nem tükrözik. Van már középiskolás és szakmunkás, de még mindig kevesen vannak a felsőoktatásban, az otthoni sikertelenség okozza, hogy nem tudnak beilleszkedni a társadalomba, az iskola nem képes őket a hagyományos módokon kezelni. Ez a tengernyi „vád” viszont nem akadályozta Czuczu Tibort abban, hogy azt is megállapítsa: a cigányok jelentős része nem különbözik a nem romáktól viselkedésben, öltözködésben, munkavállalásban, a szülői értekezleten való részvételben, s van olyan iskola, ahol még a szülöi munkaközösségbe is beválasztják őket.

Szintén kirívó példája a rasszizmusnak Ritó László Pedagógusok, ahogyan egy tanár látja címü írása. Ebben a cikkben a szerző elismeri, hogy úgy adja közre 17 község adatait, hogy azokat nem tudta leellenörizni. De szerinte mégis megközelítik a valóságot, mert felelős közösségi vezetőktől származnak, amelyek alapján azt a konzekvenciát vonta le: a 70-80 IQ érték alatti tanulók többsége cigány, még a nem roma tanulók között is több az átlagos intelligenciájú, mint az várható lenne, azaz a helyben maradó második-harmadik generációs - lakosság génállománya hanyatlást mutat. Átlag fölötti vagy igen magasan kiemelkedő intelligencia egyre kisebb számban fordul elő.

Radikális hangvételváltást jelentett Forray R. Katalin és Hegedűs T. András A cigánygyerekek iskoláztatásának néhány ellentmondása címü cikke. A két szerző részletesen vette számba a romák és az iskolák viszonyrendszerét, de a cigányokat a szociális és szociokulturális hátrányaikért nem bélyegezte meg, a kulturális hagyományaiért pedig nem ítélte el, hanem inkább a multikulturalizmus szemszögéböl tiszteletben tartotta ezeket az adottságokat, és objektív, tárgyilagos, higgadt javaslatokkal próbált meg érvelni annak érdekében, hogy a különböző területek közötti feszültségeket meg lehessen emberi módon oldani.

Tóth László Felszámoltuk az ötvenéves lemaradást Kerekasztal-beszélgetés a közoktatás fejlesztését szolgáló kutatásokról címü írása arról a fontos tényröl adott hírt, hogy az Oktatáskutató Intézetben - történeti távlatban és müködés közben Csongor Anna annak vizsgálatába kezdett, hogy milyen oktatási formációkban tanítják a roma gyermekeket, míg az Országos Pedagógiai Intézetben - Hegedűs T. András és Forray R. Katalin irányításával - az integrálódott romák sorsával foglalkoznak.

REGIO 23. évf. (2015) 4. szám 80-114. 
A hír kategória egyetlen írásában arról számoltak be, hogy a cigányok 32 százaléka végzi el bukás nélkül az általános iskolát, $\mathrm{s}$ közülük minden 3. roma tanuló továbbtanul, valamint közölték azt is, hogy az Országos Cigány Tanács szerint a cigányság foglalkoztatottságában kialakult helyzet az iskolai lemaradás következménye.

A Postánkból rovat egy olyan olvasói levelet tett közzé, amelyből az olvasók azt tudhatták meg, hogy megjelent az első cigány nyelvü újság, a Romano Nyévipé. Kerekes László Tanév eleji információk Munkában a pedagógiai asszisztensek címü írása pedig arról számolt be, hogy az 1986/1987-es tanévben 300 pedagógiai asszisztens kezdett el dolgozni, akik tehermentesítik a pedagógusokat azzal, hogy segítenek az egyéni törödést igénylö tanulók, vagy a szociális, illetve tanulási hátránnyal küzdők, köztük a roma gyermekek, fejlesztésében.

Az 1987-es év egyetlen szociális megközelítést alkalmazó írása KISZ-ösztöndíj címmel jelent meg, amely arról számolt be, hogy hátrányos helyzetü fiatalok továbbtanulását segíti a KISZ ösztöndíjjal, s a pályázatra több mint 300 állami gondozott és cigány fiatal jelentkezett.

A tárgyalt év egyetlen politikai megnyilatkozása Köpeczi Bélától származott Az intézményi demokrácia bövitéséhez a pedagógusok önállóságának és a nevelötestületek hatáskörének növelése szükséges címü írásban, amely beszámolt arról, hogy előrelépés történt, mert megalakult a Magyarországi Cigányok Kulturális Szövetsége, cigány lap is kiadásra került, és a politikai vezetés fontosnak tartja a romák felemelését, amelyhez kulcsfontosságú terület az iskoláztatás, nevelés, oktatás megszervezése, fejlesztése a roma közösség együttmüködésével.

Összegezve az 1987-es évet az állapítható meg, hogy a pedagógia gyakorlati alkalmazói körében a roma tematikát illető etnikus szemlélet rendkívüli mértékben volt erős, nem egyszer nem csak elöítéletes, de rasszista vagy felvilágosult rasszista írások is napvilágot láttak, miközben a hatalom igyekezett azokhoz a hangokhoz igazodni, amelyek deetnicizálni akarták a cigány tanulók nevelésével, oktatásával kapcsolatos kérdéseket. A Köznevelés továbbra sem foglalt állást, a roma tematikát szociális vagy etnikus szempontból megközelítők között, szinte válogatás nélkül leközölt mindent, ami arra érdemesnek tartott. 


\section{Összegzés}

1983 és 1987 között rendkívül változatos képet mutat a 109 írás, amelyeket egy összegző táblázatban az alábbiak szerint lehet kategorizálni:

\begin{tabular}{|c|c|}
\hline a roma tematika negligálása-modell & \\
\hline asszimiláció-modell & \\
\hline integráció-modell & 2 \\
\hline szegregáció-modell & 4 \\
\hline $\begin{array}{l}\text { a cigánykérdés etnikus kérdésként való } \\
\text { felfogása-modell }\end{array}$ & 14 \\
\hline $\begin{array}{l}\text { a cigánykérdés szociális kérdésként való } \\
\text { felfogása-modell }\end{array}$ & 8 \\
\hline $\begin{array}{l}\text { asszimiláció-modell - a cigánykérdés } \\
\text { etnikus kérdésként való felfogása-modell }\end{array}$ & 1 \\
\hline $\begin{array}{l}\text { szegregáció-modell }- \text { a cigánykérdés } \\
\text { etnikus kérdésként való felfogása-modell }\end{array}$ & 7 \\
\hline $\begin{array}{l}\text { a cigánykérdés etnikus kérdésként való } \\
\text { felfogása-modell - a cigánykérdés szociális } \\
\text { kérdésként való felfogása-modell }\end{array}$ & 5 \\
\hline $\begin{array}{l}\text { integráció-modell }-\quad \text { cigánykérdés } \\
\text { szociális kérdésként való felfogása modell }\end{array}$ & 1 \\
\hline $\begin{array}{l}\text { integráció modell }- \text { a cigánykérdés } \\
\text { etnikus kérdésként való felfogása-modell }\end{array}$ & 1 \\
\hline multikulturalizmus-modell & \\
\hline integrációs-szegregációs modell & 1 \\
\hline $\begin{array}{l}\text { integrációs-szegregációs modell }- \text { a } \\
\text { cigánykérdés szociális kérdésként való } \\
\text { felfogása-modell }\end{array}$ & 1 \\
\hline $\begin{array}{l}\text { integrációs-szegregációs modell }- \text { a a } \\
\text { cigánykérdés etnikus kérdésként való } \\
\text { felfogása-modell }\end{array}$ & 2 \\
\hline roma gyermekekröl szóló hír & 11 \\
\hline roma gyermekekről szóló riport & \\
\hline roma gyermekekről szóló helyzetképadás & \\
\hline $\begin{array}{lrr}\begin{array}{c}\text { roma } \\
\text { információkat } \\
\text { tanulmány }\end{array} & \begin{array}{r}\text { gyermekekre } \\
\text { tartalmazó }\end{array} & \begin{array}{r}\text { vonatkozó } \\
\text { publicisztika, }\end{array} \\
\end{array}$ & 13 \\
\hline $\begin{array}{l}\text { roma gyermekekre vonatkozó részek } \\
\text { politikusi megnyilatkozásokban }\end{array}$ & 3 \\
\hline kapcsolódó írás & 21 \\
\hline helyesbítés & \\
\hline szemle & 6 \\
\hline
\end{tabular}

REGIO 23. évf. (2015) 4. szám 80-114. 
portré

novella

módszertani írás

egyéb

8

összesen:

1983 és 1987 között 109 olyan írás jelent meg tehát a lapban, amely - részben vagy teljes egészében - kapcsolódott a roma tematikához. Ez a szám minőségi ugrás az 1978-tól 1982-ig tartó időszak 51 cikkéhez képest. Egyértelmünek tünik, hogy 1983 és 1987 között a Köznevelés írói és szerkesztői égetőbb kérdésnek érezték a cigány gyermekek iskoláztatását, mint a megelőző öt évben. 1983 és 1987 között csak egyetlen évben jelent meg 15 vonatkozó írás, a másik négy évben 22-28-szor fordult elő olyan írás, amely a roma gyermekek tanításával foglalkozott.

Változás az 1978 és 1982 közötti időszakhoz képest a kapcsolódó írások magas aránya. A 109 szakcikknek körülbelül az ötödét tették ki olyan írások, amelyek a szegregáló oktatási rendszert kritizálták. Sok esetben nem nevesítették a cigány tanulókat, de ötéves távlatból egyértelmüvé válik, hogy a gyógypedagógiai intézményrendszer lakmuszpapírja a cigány tanulók sikeressé tételének mikéntje volt, $\mathrm{s}$ hogy a kisegítő iskolában való - rendkívül magas - arányuk jelezte azt, hogy a gyógypedagógiai intézményhálózat, a nevelési tanácsadói rendszer, az áthelyező bizottságok munkája sok kívánnivalót hagy maga után, ezért meg kell reformálni.

1983 és 1987 között többször kimondták azt a Köznevelés hasábjain, hogy a roma gyermekeknek - a kirekesztettségükből adódóan - olyan szociális és szociokulturális lemaradásuk van, amely miatt nem tudnak eredményesek lenni abban az oktatási rendszerben, amely teljesen intoleráns az ö adottságaikkal szemben, s ezért az értelmi fogyatékossá minősítés eszközét használja arra, hogy megszabadulhasson tölük.

Az 1983 és 1987 közötti írásokról az is elmondható, hogy a szerzők ritkán ismerték fel azt, hogy nem a cigány tanulók a felelösek a hátrányaikért, hanem az oktatási rendszer azon merevsége, amely képtelen idomulni a megváltozott szociális és szociokulturális hátterü gyermekösszetételhez, ugyanakkor érzékelhető volt az, hogy továbbra is nagy volt az információéhség a roma tanulókkal kapcsolatosan. Rengeteg adatot közölt a Köznevelés

REGIO 23. évf. (2015) 4. szám 80-114. 
országos és megyei szinten a cigány diákokat jellemző sikerekről és kudarcokról.

Ami megdöbbentő a Köznevelés cikkeit olvasva, hogy a lap Janus-arcúsága öt év alatt mit sem változott. Rendszeresen jelentek meg olyan írások a romákról és gyermekeikről, amelyek azt sugallták, hogy a cigány közösség olyan primitív és destruktív, vad nép, amelyet csak akkor lehet megsegíteni, ha a jóindulatú fehérek heroikus küzdelmeket vívnak érte irdatlan mennyiségü anyagi eszköz beleinvesztálásával. S természetesen nem lehet elmenni szó nélkül amellett sem, hogy az oktatási hetilap közölt olyan kifejezett rasszista vagy felvilágosult rasszista írásokat, amelyek napjainkban nem türnének nyomdafestéket, tetézve azzal a szomorú ténnyel, hogy ennek az irányzatnak az egyik főképviselője egy roma származású szakfelügyelö volt.

REGIO 23. évf. (2015) 4. szám 80-114. 